\title{
The Meaning of Membership in Motorcycle Community in the Campus
}

\author{
Hendro Prabowo \\ Faculty of Psychology \\ Gunadarma University \\ Depok, Indonesia \\ ndrahu@yahoo.com
}

\author{
M. Ihsan Sulthoni \\ Faculty of Psychology \\ Gunadarma University \\ Depok, Indonesia \\ ihsan.sulthony@gmail.com
}

\author{
M. Purwani Dewi \\ Faculty of Psychology \\ Gunadarma University \\ Depok, Indonesia \\ mp_dewi@yahoo.com
}

\begin{abstract}
In 2017, there are 113 million motorcycles in Indonesia or $43 \%$ of the total population of 264 million. With this amount, of course there are also many motorcycle communities and/ or motorcycle gangs. Many social and psychological studies have been done and found positive aspects of motorcycle communities and negative aspects of motorcycle gangs. In addition, the previous studies are mostly descriptive in nature and no more interpretive meanings. So, this research aims to explore the meaning of being a member of the motorbike community on campus. This research is a case study involving five participants to answer research questions: What the meaning of the motorcycle community for you? Do you have personal problems? Why? The result consists five themes including intention of gathering, community as a place to avoid problems, community as a place to cope stress, and aspiration of the founder. Psychological perspective and intervention to promote safety riding are discussed.
\end{abstract}

Keywords: membership, motorcycle community, campus

\section{INTRODUCTION}

The number of motorcycles in Indonesia is 113 million or $43 \%$ of the total population of 264 million [1]. Compare this with the United States [2], with a population of 325.7 million having only 8.4 million motorcycles $(2.4 \%$ of the population). With this amount, surely there are also many motorcycle communities in Indonesia. Some of the motorcycle communities were established based on vehicle brands. The results of the study of this phenomenon obtained from Google Scholar obtained 19,600 scientific works. The reviews of the several scientific papers show a difference between motorcycle communities and motorcycle gangs, where communities have better and positive connotations than motorcycle gangs. Several studies of the motorcycle community have found positive themes about solidarity [3, 4, 5] and safety riding [3]. While negatively, the themes that emerge are the desire to be appreciated and accepted in the society [6] and reduced time for families [5]. On the contrary, the results of research on motorcycle gangs found themes such as juvenile delinquency [7, 8, 9], broken home families [7, 8], lack of attention and love [8, 9], freedom and feeling valued [9], and solidarity for negative actions [7], in the form of aggressiveness [10].

Two cities known as motorcycle gangs are Bandung and Jakarta. In Bandung, there are four biggest motorcycle gangs, Moonraker, Exalt to Coitus (XTC), Seven Brigade (Brigez), and Grab on Road (GBR). Moonraker, established in 1978, is thought to be the origin of all motorcycle gangs in the city of Bandung. Moonraker is taken from one of the James Bond movie titles and has a symbol of adoption of the "Hell Angel", symbol from the United States' motorcycle gangs. This group also developed into other regions around the city of Bandung [11]. In Jakarta, there are two main and conflicting gangs, the City of China Forces (Pachinko), which were founded in the 1970s and YGeneration (GEN-Y), which first emerged in the 1990s. Although the population of Jakarta is quite large, the motorcycle gang hardly reflects the size and dominance of their counterparts in West Java [12].

In the United States, the term that is widely used is the club and sometimes with negative connotations. According to Barker \& Human [13], motorcycle clubs (MCs) divided into conventional and deviant clubs. The most deviant clubs are $1 \%$ or outlaw motorcycle gangs (OMGs). The Big Four OMGs are the Hells Angels MC, the Outlaws MC, the Bandidos MC, and the Pagans MC. The first three, where in American based, have international chapters and are the largest motorcycle gangs in the world (over country borders). Some studies of OMGs show that they are involved in various criminal activities $[13,14,15]$. So, the connotation of motorcycle gangs in the US seems to be more severe than motorcycle gangs in Indonesia. While the motorcycle community or conventional motorcycle seems not to be used as much material for study. In the US, there is a few studies of this group and some of its focus is on brands and solidarity, even though this group also crossed national borders (e.g. [16]).

In addition to the motorcycle community that develops in communities that sometimes cross regional boundaries (such as OMGs in the US or communities based on brands in the US and Indonesia), there is also a motorcycle community that has headquarters on university campuses that relatively do not cross regional boundaries. This group has a more positive connotation because it has activities such as safety riding, social services, and touring. This group has grown in considerable numbers in Indonesia, the United States and Australia; but the literature review of this phenomenon is still relatively rare. Two literatures were found on two campuses in Nigeria and Thailand. Umebese \& Okukpo [17] found that motorists on campus only produced little stress, but motorcycle accidents on the Khon Kaen University campus were still relatively high for the academic community. 
According to Satiennam, Jaensirisak, Natevongin \& Kowtanapanich [18], 75\% of trips are made on motorcycle on campus. Their study proposes integrated demand and supply-side policies to promote the bus transportation system. They also found that campus buses must be free and prioritized. If not, motorcycle must be restricted in academic zones and subject to parking fees.

\section{THE RESEARCH STUDY}

The researchers found a motorcycle community called GRTC from a private university in the East Jakarta area, where is not far from the researcher's residence. In 1996, the university was founded on the development of the Higher Education of Health, Higher Education of Economics and Management and Higher Education of Information Technology. Now, this university has four faculties namely the Faculty of Computer Science, the Faculty of Economics, the Faculty of Health, the Faculty of Teacher Training and Education.

GTRC was founded on 10 November 2017, is a student social organization. Initially, the student often gathered together after class and traveled together. By one of the lecturers at the campus, the GTRC motorcycle community was developed to be able to use the road as a public space. The community has a vision and mission that they make together, they also have rules that must be used as a reference for their members. The vision of the GRTC community is to build togetherness among members so that they will get closer to each other, while its mission is to increase experience and carry out collective gatherings for sharing sessions. Since 2018, there have been 35 students as members, of which 15 are active (consisting of 11 students and 4 female students). Two lecturers are also active as founders. Of the 15 active members there are 10 people who are very active in sharing session activities. They are generally also called extension class students, where the lecture hours are afternoon to evening on weekdays and lecture hours on Saturdays are morning to evening. On Saturday evening after class, they use the time to gather until late at night, about $10.00 \mathrm{pm}$.

The purpose of this study is to explore the meaning of being a member of the motorcycle community on campus, especially to better understand the psychological dimension compared to previous studies which are more descriptive of the phenomenon. Motorcycle community on campus means a community where members are motorcycle users and are part of the university (lecturers and students); and also has headquarters on university campus. For exploring the meaning of being a member, this research also probes to dig deeper into descriptive data. This research is a case study involving 5 participants (1 lecturer and 4 students) to answer research questions: What the meaning of the motorcycle community for you? Do you have personal problems? Why? The participant data used as in TABLE I.

As in any other qualitative study, the data collection and analysis occur concurrently. Data were collected includes interviews, direct observations, and participant-observation. Data analysis was carried out with pattern-matching, a technique for linking data to the propositions [19].
TABLE I. PARTICIPANT

\begin{tabular}{|l|l|l|l|l|}
\hline \multicolumn{1}{|c|}{ Initial } & \multicolumn{1}{c|}{ Age } & \multicolumn{1}{c|}{ Sex } & \multicolumn{1}{c|}{ Status } & Position \\
\hline $\mathrm{p}$ & 24 & Male & Student & Leader \\
\hline $\mathrm{BB}$ & 52 & Male & Lecture & Founder \\
\hline $\mathrm{Y}$ & 24 & Male & Student, employee & Member \\
\hline $\mathrm{Z}$ & 25 & Male & Student & Member \\
\hline AS & 24 & Male & Student & Member \\
\hline
\end{tabular}

\section{RESULT}

The results of the study consisted of themes including intention of gathering, community as a place to avoid problems, community as a place to cope stress, and aspiration of the founder.

\section{A. Intension of Gathering}

Campus location on Raya Bogor Street which is access from East Jakarta to the city of Bogor. This road is a busy road in office hours. Two big markets, shopping centers, factories and access to Halim Perdanakusuma airport are on this road. The campus has a yard that is used for parking cars and motorcycle. There are several buildings near parking lots such as mosque, café and kindergarten school. Community members and other non-member students can gather together at the cafe. The veranda of the kindergarten school is sometimes also used by community members to gather when not in use. Based on observations, there are some students gathered at the café or courtyard around the campus. The gathering time is after completing class, in the afternoon around 4:00 - 7:00 a.m.

For $\mathrm{P}$ and $\mathrm{Y}$, who are both students, this gathering activity is generally gathered after class, especially at the end of the week. Y said: ... every time we finish class we gather together. Or P, who said: ... I often do after class, which is every Saturday and Sunday ...

Activities at this gathering are sharing among members, making them feel more pleasant. BB says: ... we just share each other there is no special way, discussing what makes us happy ... Chat that appears in this activity is a daily problem. AS said: ...it was like family problems, girlfriend problems, college assignments, street problems like being hit by police raids.

\section{B. Community as a Place to Avoid Problems}

For $\mathrm{BB}$ and $\mathrm{P}$, the motorcycle community is meant as place to avoid problems. BB is a widower twice divorced, and after living alone, he considered motorcycle and the motorcycle community as his new life mate. BB said, ...first I like motorcycle, secondly, I like to chat with friends, thirdly I fill my solitude, because I have separated from my first and second wives. So, I am now living alone, so motorcycles are my life companion everywhere, ... I can live quietly, I can teach on campus, it is enough that I can be happy fun ...

While $\mathrm{P}$ is a migrant from the city of Medan who moved to Jakarta because he wanted to avoid his parents who were considered authoritarian. ... my family, especially my father, is very authoritarian, for example: I may not go home late at 9:00 a.m., it is always prohibited if it is not according to the wishes of the father. So, I prefer lodgings with the reason 
that they are close to campus, even though I want to be away from parents in Medan. ... in Medan I do not feel free, and I do not like to be organized, because I am an adult and able to take care of myself.

$\mathrm{P}$ and $\mathrm{BB}$, both agree that the motorcycle community has made them better. $\mathrm{P}$ said: .... this motorcycle club increasingly made me calm, because .. the activity of gathering together with community friends. Z said: ... With the GRTC community I feel I have a new family that can help at any time. I feel happy that there is a GRTC motorcycle community whose members are college friends; they have been supporting me all this time.

For Z, involve in the motorcycle community he felt he had a new family. Relations with his family who always misunderstand, makes $Z$ rarely chat together. Because $Z$ still lives with his parents, he always rarely goes home or when he comes home late at night, so he just avoids it. I feel less appreciated, so I am often disappointed with family talk or ignorance of family who rarely talk to me. I once had an accident, instead of defending me, even scolding me was said to be inadvertent, just like you said you were drunk huh'. So I feel happy that there is a GRTC motorcycle community who's the members are college friends, they have always been supportive.

The three participants (BB, $\mathrm{P}$ and $\mathrm{Z}$ ) felt uncomfortable when at home, then they seemed to want to "escape" from this uncomfortable situation and find it in the community; this happens repeatedly, so it becomes a kind of addiction.

BB says about the uncomfortable and feels free when socializing: At least in a week as the longest ...... released away on a motorcycle and socialized every time.

\section{Community as a place to cope stress}

Both student participants ( $\mathrm{Y}$ and AS) can use the motor community as a way to deal with stress and anxiety. Y has a personal problem in managing work time with college. ... I work from morning to night, from Monday to Saturday, so if there is a lecture on weekdays, I like to stress myself ... While the AS has an anxious trait. I am an anxious person, for example if my assignment is not finished, sometimes I am worried that my grades will be $D$ or $C$, like the presentation to be nervous talking in front of my friends, just confused. By being involved in the community, both can cope the problem. Y said: ... I also need refreshing so I tried to find an empty time. ... gathered together with college friends or the GRTC community, every time after class. While the AS can cope its college problems, ... but with the GRTC community, I can share with the members about college assignments.

\section{Aspiration of the Founder}

As a community founder, BB has aspirations for community members to have self-awareness and obey the traffic. He said: ... Because motorcycles are identical to the streets, member must be self-aware... For BB, self-aware are the member own conditions in terms of health and respect for road users. BB said: ... each person's selfcondition ... can understand their condition, if they feel unhealthy do not have to ride a motorcycle, also if riding a motorcycle, they must respect each other vehicle users.
In addition, BB hopes that self-awareness and obey the traffic not only applies to community members but also to other students who are not members, ...obey the traffic so that they give an example to friends on campus who don't want to join in the community. Through sharing sessions that are often held on campus, BB hopes community members can be a paragon, good example for other students. ...at least the members already understand the function of the traffic signs. That way can give a good example to other students by sharing sessions.

\section{DISCUSSION}

According to Nakken [20], individuals who grow up in neglectful families often unconsciously that they are being abused. Ideally, children grow in families that are full of interaction and nurturing. But in neglectful families, children don't get this. They become underdeveloped and have low self-esteem. Thus, they leave their neglectful homes more susceptible to the seductive element found in the addictive process. Powerful events, powerful people, and powerful objects, in this case: motorcycle and community, to hold some truth, others want to attach themselves; it is as if these people or objects can fill their emptiness. Firman and Gila [21] noted that they were treated not as unique individuals or humans, but only as objects. Caregivers generally don't see them as their true selves. Because of the blurring of this basic wound, a person "throws" himself towards all kinds of addictions, and maybe drags it for wealth, power, and violence; all of which built up his original life.

Firman and Gila [21] added that in the addictive processes, there is often a continuous cycling between positive and negative experiences: the initial feeling of comfort from acting out the addiction; then guilt, shame, remorse; then more acting out to gain comfort; and so on. This cycling, even a destructive, but it serves to hide the wound.

\section{RECOMMENDATIONS}

From an ecological perspective, community capacity building is defined as terms of efforts to increase current and future local resources problem solving [22]. The community intervention that was recommended for the motor community in this study was based on previous studies. Initially, there are many studies proved that from a trait perspective, conscientiousness (carefulness) has a stronger direct effect on the driving behavior and accident risk (e.g. $[23,24])$. Second, as contrary, Kerr [25] proposed a new term for the phenomenon: "the driving without attention mode". He sees the main characteristic of this state as the loss of awareness due to automatizing processes of perception induced by a highly predictable visual scene. Brown [26] claims that a new definition of the phenomenon is necessary. A differentiation between how sleep, trance and attention each influence the phenomenon would enable experimental validation. Brown [26] himself again uses a descriptive definition of what he calls "driving without awareness" which assumes that drivers are oblivious to impending collisions. So, based on the contradiction term 
above, some scholar now use term: "mindfulness and mindlessness".

Driving is a multitasking activity that requires drivers to manage their attention between various driving and nondriving-related tasks. For instance, during driving, a driver not only focuses his or her attention on the driving task, but at the same time is aware of what is happening around them. This involves making judgement about other road user's actions so that they can anticipate happenings on the road [27]. This is an inattention phenomenon, have some similarity to an individual with less mindful, or demonstrating mindlessness. According to Brown and Ryan [28], a "mindless" person tends to be less attentive and aware of the present moment. Langer added: "When in a mindless state, an individual operates much like a robot; thoughts, emotions, and behaviors (hereafter just behaviors) are determined by 'programmed' routines based on distinctions and associations learned in the past" [29]. In driving, Segal, Teasdale, \& Williams [30] added that when driving on a familiar route, of suddenly realizing that one has been driving for miles "on automatic pilot," unaware of the road or other vehicles, preoccupied with planning future activities or ruminating on a current concern. Contrary, mindful driving is associated with being fully in present moment, consciously aware of sights, sounds, thoughts, smell and body sensations as they arise.

Ledesma, et al [31] found that driving errors are strongly associated with general error proneness, lack of attention when performing everyday activities, and dissociative personality traits. In line with this, Kass, Cole, and Legan [32] reviewed literature on driver distraction focusing on situational awareness. They suggested that mindfulness training may assist in educating drivers on how to be more aware of external and internal stimuli that are relevant to driving, stress and distraction. Kass \& VanWormer [33] found that mindfulness and concentration levels were both significantly related to situation awareness for driving. Mindfulness training also has a high impact actual driving performance over time by improving drivers' awareness of their environment and enabling them to block out distractions and to quickly identify hazards. From a total of 309 drivers responded via online questionnaire, Stephens, Koppel, Young, Chambers, \& Hassed [34] found that mindfulness had negative relationships with driving anger and aggressive driving.

The first author is currently designing a community intervention called Mindful Motorcycling. This program is based on means that mindfulness means paying attention in a particular way: on purpose, in the present moment, and nonjudgmentally [35]. The community members are asked to do a kind of 'waking meditation', while driving from home to campus. Before driving, she/ he was asked to be aware of the present moment which was riding a motorcycle. When driving, this consciously aware consist of the sights, sounds, thoughts, smells and body sensations on the street. The present moment awareness is also done so that the driver always looks for something new, not in a hurry, and does not focus on destination. Meanwhile, nonjudgmentally implemented in other vehicle situations cut the road, other vehicles overtake, when stopped at a traffic light, and stuck in jam.

\section{REFERENCES}

[1] Cental Bureau of Statistics. Development the number of Motorized Vehicles by Type (in Indonesian), 1949-2017. https://www.bps.go.id/linkTableDinamis/view/id/1133, 2017.

[2] Motorcycles registered in the United States, 2002-17 - IIHS-HLDI. https://www.iihs.org/frontend/iihs/documents/masterfiledocs.ashx?id= 2145, 2017.

[3] R. Prayudi, Role of the Motor Club in the Formation of Safe Drivinf Behavior (Safety Riding). Sociology Perspective (in Indonesian). Vol 2, no 1 pp 1-12, 2013.

[4] B. Adam, Social Capital in the Vespa BananaCity150 GedanganSidoarjo District. Paradigma, vol 2, no 2, pp 1-5, 2014 (in Indonesian).

[5] E. Sari, P. Lestari, Factors Underlying the Formation of YYKC (Yin Yang King Club) Motor Community Yogyakarta. E-Societas, vol 6, no 3, pp 1-18, 2017 (in Indonesian).

[6] S. Ismail, Vespa Community in Makassar City (Lifestyle Study). Thesis in Hassanudin University, Makasar, 2014 (in Indonesian).

[7] I. Matondang, Juvenile Delinquency in the Mod Game Community (Case Study of P-Dox Duren Sawit Jakarta Timur Teenage Motorcycle Gang). Thesis in Departement of Sociologi National Islamic University Jakarta, 2011 (in Indonesian).

[8] E. Hardiansyah, External Factors that Cause Teenagers. Muhammadiyah University, Malang, 2012 (in Indonesian).

[9] S. T. Raharjo, S. Humaedi, B.M. Taftazani, Family Factors in Juvenile Delinquency: Descriptive Study of Motorcycle Gangs in the Bandung city. Sosiohumaniora, vol 14, no3, pp. 212-221, 2012 (in Indonesian).

[10] L. Armayati, Motorcycle Gangs in Social Psychology Review. AnNafs, vol 5 no 1, pp. 57-72, 2011 (in Indonesian).

[11] M. Muchlis, Motorcycle Gang Violence. Communication Science Journal, vol, 1, no 02, pp. 202-218, 2011 (in Indonesian).

[12] E. Mariz, R. Widodo, Rebels Without A Cause: Inside Indonesia's Violent Biker Gangs. Journal Indonesia 360 . http://srindonesia.com/read/rebels-without-a-cause-inside-indonesia-sviolent-biker-gangs (n.d).

[13] T. Barker, K.M. Human, Crimes of the Big Four motorcycle gangs. Journal of Criminal Justice, vol 37, no 2, pp. 174-179, 2009.

[14] R. C. Smith, Dangerous Motorcycle Gangs: A Facet of Organized Crime in the Mid Atlantic Region. Journal of Gang Research, 9(4):3344, 2002.

[15] J. Ayling, Pre-emptive Strike: How Australia is Tackling Outlaw Motorcycle Gangs. American Journal of Criminal Justice, 36(3): 250264, 2011.

[16] D.M. Austin, P. Gagné, Community in a Mobile Subculture: The World of the Touring Motorcyclist. In Studies in Symbolic Interaction . Emerald Group Publishing Limited, 2008, pp. 411-437.

[17] P. F.A Umebese, S.U. Okukpo, Motorcycle Accidents in a Nigerian University Campus. A One Year Study of the pattern of Trauma Sustained in the University of Benin Campus. Nigerian Journal of Clinical Practice, vol 4, no 1, pp. 33-36, 2001.

[18] T. Satiennam, S. Jaensirisak, N. Natevongin, M. Kowtanapanich, Public Transport Planning for a Motorcycle Dominated Community. Journal of the Eastern Asia Society for Transportation Studies,vol 9, pp 970-985, 2011.

[19] P. Baxter, S. Jack, Qualitative Case Study Methodology: Study Design and Implementation for Novice Researchers. The Qualitative Report, vol 13 no 4, pp 544-559, 2008.

[20] C. Nakken, The Addictive Personality: Understanding the Addictive Process and Compulsive Behavior. Center City, Minnesota: Simon and Schuster, 2009.

[21] J. Firman, A. Gila, The Primal Wound: A Transpersonal View of Trauma, Addiction, and Growth. New York: Suny Press, 1997. 
[22] E. J. Trickett, Community Psychology: Individuals and Interventions in Community Context. Annual Review of Psychology, vol 60, pp 395-419, 2009.

[23] W. Arthur Jr, W.G. Graziano, The Five - Factor Model, Conscientiousness, and Driving Accident Involvement. Journal of Personality, vol 64, no 3, pp. 593-618, 1996.

[24] N. Sümer, T. Lajunen, T. Özkan, Big Five Personality Traits as the Distal Predictors of Road Accident. Traffic and Transport Psychology: Theory and Application, vol 215, pp 215-227, 2005.

[25] J. S. Kerr, Driving Without Attention Mode (DWAM): A Formalisation of Inattentive States While Driving. In A.G. Gale,I.D. Brown, C.H. Haslegrave, I. Moorhead, S.P. Taylor, S.P. (Eds.), Vision in Vehicles III . Amsterdam: Elsevier, 1991, pp. 473-479.

[26] I.D. Brown, Highway Hypnosis: Implications for Road Safety Researchers and Practitioners. In A.G. Gale,I.D. Brown, C.H. Haslegrave, I. Moorhead, S.P. Taylor, S.P. (Eds.), Vision in Vehicles III. Amsterdam: Elsevier, 1991, pp. 459-466.

[27] A Hanan S. M.J. King, I.M. Lewis, Are You a Mindful Driver? A Review of the Potential Explanatory Value of Mindfulness in Predicting Speeding Behaviour, 2010. [In Proceedings of 2010 Australasian Road Safety Research, Policing and Education Conference. The Road Safety Research, Policing and Education Conference, 2010].

[28] K.W. Brown, R.M. Ryan, The Benefits of Being Present: Mindfulness and its Role in Psychological Well-Being. Journal of Personality and Social Psychology, vol 84, no 4, pp. 822, 2003.
[29] E.A. Haigh, M.T. Moore, T.B. Kashdan, D.M. Fresco, Examination of the Factor Structure and Concurrent Validity of the Langer Mindfulness/Mindlessness Scale. Assessment, vol 18, no 1, pp. 1126, 2011.

[30] Z.V. Segal, J. D. Teasdale, J. M. G. Williams, Mindfulness-Based Cognitive Therapy: Theoretical Rationale and Empirical Status, 2004.

[31] R. D. Ledesma, S. A. Montes, F. M. Poó, M. F. López-Ramón, Individual Differences in Driver Inattention: The Attention-Related Driving Errors Scale. Traffic Injury Prevention, vol 11, no 2, pp. 142-150, 2010

[32] S.J. Kass, K. Cole, S. Legan, The Role of Situation Awareness in Accident Prevention. In Smet AD, editor. Transportation Accident Analysis and Prevention. New York: Nova Science Publishers, Inc. 2008, pp. 107-22.

[33] S. J. Kass, L.A. VanWormer, W.L. Mikulas, S. Legan, D Bumgarner, Effects of Mindfulness Training on Simulated Driving: Preliminary Results. Mindfulness, vol 2, no 4, pp. 236-241, 2011.

[34] A. N. Stephens, S. Koppel, K.L. Young, R. Chambers, C. Hassed, Associations Between Self-Reported Mindfulness, Driving Anger and Aggressive Driving. Transportation Research Part F: Traffic Psychology and Behaviour, vol 56, pp 149-155, 2018.

[35] J. Kabat-Zinn, T.N. Hanh, Full Catastrophe Living: Using the Wisdom of Your Body and Mind to Face Stress, Pain, and Illness. Delta, 2009. 